\title{
HIP SIZES ANALYSIS AT VARIOUS PARITY IN INDONESIAN LOCAL ETTAWAH GOATS AS A SELECTION BASIS OF DOE CANDIDATES
}

\author{
Mudawamah Mudawamah $^{1 *}$, Villa Vavilla ${ }^{2}$, Dedi Suryanto ${ }^{3}$ and Mohammad Zainul Fadli ${ }^{4}$ \\ ${ }^{1}$ University of Islam Malang, Department of Animal Husbandry,Jalan MT. Haryono 193, Malang 65151, Indonesia \\ ${ }^{2}$ University of Islam Malang, Department of Animal Husbandry,Jalan MT. Haryono 193, Malang 65151, Indonesia \\ ${ }^{3}$ University of Islam Malang, Department of Animal Husbandry,Jalan MT. Haryono 193, Malang 65151, Indonesia \\ ${ }^{4}$ University of Islam Malang, Department of Medical,Jalan MT. Haryono 193, Malang 65151, Indonesia \\ Email- mudawamah@unisma.ac.id
}

https://doi.org/10.35410/IJAEB.2021.5678

\begin{abstract}
The study aimed to determine the hip size of Indonesian Local Ettawah Goats (Peranakan Ettawah or PE) from various parity as a selection criterion for candidate goats that could be kidding without dystocia. This research method was a case study with purposive sampling that chose healthy reproductive goats marked by normal category relation with the duration of pregnancy, the age of first pregnancy, and the kidding process. Variable observed was hip length and width, and data analysis used descriptive analysis through mean and variance as well as one-way variance analysis. Hip measurement of Indonesian Local Ettawah Goats from 1st to fifth parity showed the average hip-length ranged from $82-85.67 \mathrm{~cm}$ and hip height varied between 19.60-21.33 cm. The variance analysis showed that the types of parity had a very significant difference $(\mathrm{P}<0.01)$ on the height hips but had significant difference $(\mathrm{P}<0.05)$ on the width-hips, with the variance of hip height and width, ranged 0.33-5.90 and 0.33-1.00. Hip height and width increased as high parity (1st until 3rd), while 4th and 5th parity were relatively constant in hip size. Determination coefficients between parity and hip height and width were $35,00 \%$ and $36,30 \%$. This study concluded that the variance of hip width was smaller (more consistent) than the hip height of Indonesian Local Ettawah Goats. One of the basic selection criteria for Indonesian Local Ettawah doe candidates was hip-width with 19,60 cm or more.
\end{abstract}

Keywords: Hip Length And Width, Goat, Parity.

\section{INTRODUCTION}

Research on hip size in livestock has been carried out, including hip size for identification of goat breeds[1]-[4], buffalo breeds[5], cattle breeds[6],[7], and sheep breeds[8]. The goat hip was used as an animal model for hip therapy or treatment in humans based on the collagen of the labrum area[9].

Indonesian Local Ettawah Goats result from a cross between Ettawah goats and Local goats, known as PE goats. These goats are very popular and have high adaptability, and are widespread in all provinces in Indonesia. Based on sex, Indonesian Local Ettawah goats is the largest population which an average ownership sex ratio per breeder of 5-10 does and one buck. So that the increase of the Indonesian Local Ettawah goat population is strongly influenced by does reproduction performance. The importance of research on the reproduction of local goats includes Black Bengal Goat from Bangladesh[10], Boer goat[11], Kacang Goat[12]. 
Vol. 06, No. 05; 2021

ISSN: $2456-8643$

Good reproduction of does could be seen based on hip size (width and height). The hip size of a doe or candidate doe was varied depending on the breed. The hip width of Uganda Local does [13] was $78.3 \mathrm{~cm}$ and $46.50+0.93 \mathrm{~cm}$ in Bengal Bangladesh Black Ewes aged 12 months[14].

The hip size of the doe indicated ease in kidding which was reflected in its parity. Parity was a period in the reproductive goat with a kidding indication which to terms, namely primipara and pluripara. Supported by research that showed a significant correlation between body size with parity [15]. It was necessary to research on the relationship of the does hip size to various parity as the basis for one of the selection criteria of the Indonesian Local Ettawah doe candidates.

\section{MATERIALS AND METHODS}

The research method was a case study at the goat breeding center in Maliran Village, Ponggok District, Blitar Regency. Geographically, the research location was located at an altitude of 167 masl with an area of $1,588.79 \mathrm{~km}^{2}$ with temperatures ranging from $18^{\circ}-30^{\circ} \mathrm{C}$, air humidity $55 \%$ - $85 \%$, with the highest rainfall 2,618.2 $\mathrm{mm}$ per year and the lowest $1,024,7 \mathrm{~mm}$ per year.

The material used 33 does with the 1st, 2nd, 3rd, 4rt, 5th parity, kept in the same environment with relatively the same nutrition. Does and kids were placed in one cage with intensive management while the buck was placed separately.

The research data were primary data through directly measuring the hip height and width while supporting data obtained from the interviews directly. The variable observed were hip sizes. The hip height was measured from the highest distance in the lumbar vertebrae, perpendicular to the ground's surface. The measurement was done with a measuring stick in units of $\mathrm{cm}$. The hip's width was measured between the right and left sides at the hip joint (protrusion of the upper femur bone). The measurement was done with capillaries in units of $\mathrm{cm}$. Measurements of hip height and width can be seen in the following figure 1. 


\section{International Journal of Agriculture, Environment and Bioresearch}

Vol. 06, No. 05; 2021

ISSN: $2456-8643$
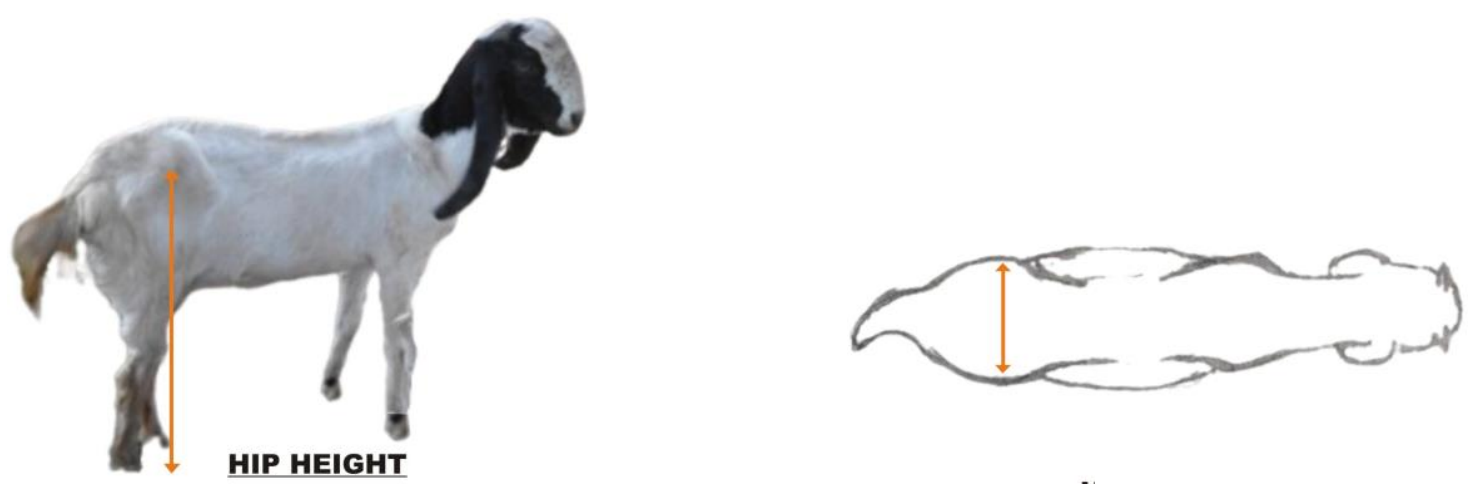

Figure 1: Measurements of hip height (left) and hip width (right)

The research procedures were to select the ILEG parent to be used for research directly in the breeder and followed by an interview. The does with normal reproductive performance were used as the research sample and classified according to the $1^{\text {st }}, 2^{\text {nd }}, 3^{\text {rd }}, 4^{\text {rd }}, 5^{\text {th }}$ parity types and was measurement of the hip height $(\mathrm{HH})$ and width $(\mathrm{HW})$.

Data analysis used one-way ANOVA with IBM Statistics 19 software. If there were significant differences, proceed with the Least Significant Differences (LSD) to find out the differences between treatments. In addition, regression analysis with linear correlation was also carried out between parity and $\mathrm{HH}$ and $\mathrm{HW}$.

\section{RESULTS}

The use of one-way variance showed that results with parity 1 to 5 having hip height were very significant $(\mathrm{P}<0.01)$, but the hip-width was significantly different $(\mathrm{P}<0.05)$, Table 1.

Table 1: Mean and variace of hip height dan width

\begin{tabular}{|c|c|c|c|c|}
\hline \multirow{2}{*}{ Parity } & \multicolumn{2}{|c|}{ HH } & \multicolumn{2}{c|}{ HW } \\
\cline { 2 - 5 } & mean $(\mathrm{cm})$ & Variance & mean $(\mathrm{cm})$ & variance \\
\hline 1 & $82.00^{\mathrm{a}} \pm 1.56$ & 2.44 & $\begin{array}{c}19.60^{\mathrm{a}} \pm \\
0.70\end{array}$ & 0.46 \\
\hline 2 & $82.80^{\mathrm{ab}} \pm 1.75$ & 3.07 & $20.10^{\mathrm{ab}} \pm 0.88$ & 0.77 \\
\hline 3 & $84.29^{\mathrm{bc}} \pm 2.43$ & 5.90 & $21.00^{\mathrm{b}} \pm 1.00$ & 1.00 \\
\hline 4 & $84.67^{\mathrm{bc}} \pm 0.57$ & 0.33 & $\begin{array}{c}21.00^{\mathrm{b}} \pm \\
1.00\end{array}$ & 1.00 \\
\hline 5 & $85.67^{\mathrm{c}} \pm 0.57$ & 0.33 & $\begin{array}{c}21.33^{\mathrm{b}} \pm \\
0.57\end{array}$ & 0.33 \\
\hline
\end{tabular}

${ }^{\mathrm{a}, \mathrm{b}}$ Notation difference was significant at the 0.05 level

The regression linier between parity and hip height, parity and hip weigth, beside that the correlation and coefficient of determination was be seen in Table 2. 
Table 2: Regression linier between parity and Hip Height and Width

\begin{tabular}{|l|l|l|}
\hline \multicolumn{1}{|c|}{ Items } & \multicolumn{1}{c|}{ Parity and $\mathrm{HH}$} & \multicolumn{1}{c|}{ Parity and HW } \\
\hline $\mathrm{R}$ & 0.591 & 0.603 \\
\hline $\mathrm{R}^{2}$ & 0.350 & 0.363 \\
\hline Regression sig. & 0.000 & 0.000 \\
\hline $\mathrm{b}$ & 0.366 & 0.750 \\
\hline $\mathrm{a}$ & -28.104 & -12.866 \\
\hline $\begin{array}{c}\text { Regression } \\
\text { equation }\end{array}$ & $\mathrm{Y}=-28.104+0.366$ & $\mathrm{Y}=-12.866+0.750 \mathrm{X}$ \\
\hline
\end{tabular}

\section{DISCUSSION}

Table 1 showed that does with the 1st to 3rd parity had hip height and width was increased as high parity, while 4th and 5th parity were relatively constant in hip size (Figure 2). The cause of the tendency for differences in hip height and significant differences in the hip width of varied parity was thought to be due to the high and low power of the uterine elasticity. The higher parity meant, the older the does age, the more elasticity of the uterus to return to normal after childbirth. It was supported by an opinion stating that during pregnancy, there would be an increase in the size of the vertebral segment, including the lumbar area associated with the width and height of the hip.[16]

Table 1 showed that does with the $1^{\text {st }}$ to $3^{\text {rd }}$ parity had hip height and width was increased as high parity, while 4th and 5th parity were relatively constant in hip size (Figure 2). The cause of the tendency for differences in hip height and significant differences in the hip width of varied parity was thought to be due to the high and low elasticity of the uterine. The higher parity meant, the older the does age, the more elasticity of the uterus to return to normal after kidding. The size of the vertebral segment during pregnancy increased, including the lumbar area associated with the width and height of the hip.[16].

Composite hip bones were related to the abdominal and uterine spaces, important for fetal development during pregnancy. Following the opinion that stated that the development of goat fetuses in the uterus in the second semester (50-100 days) and third (> 100 days) moved towards abdominal cranio-ventral.[17]. 
Vol. 06, No. 05; 2021

ISSN: $2456-8643$

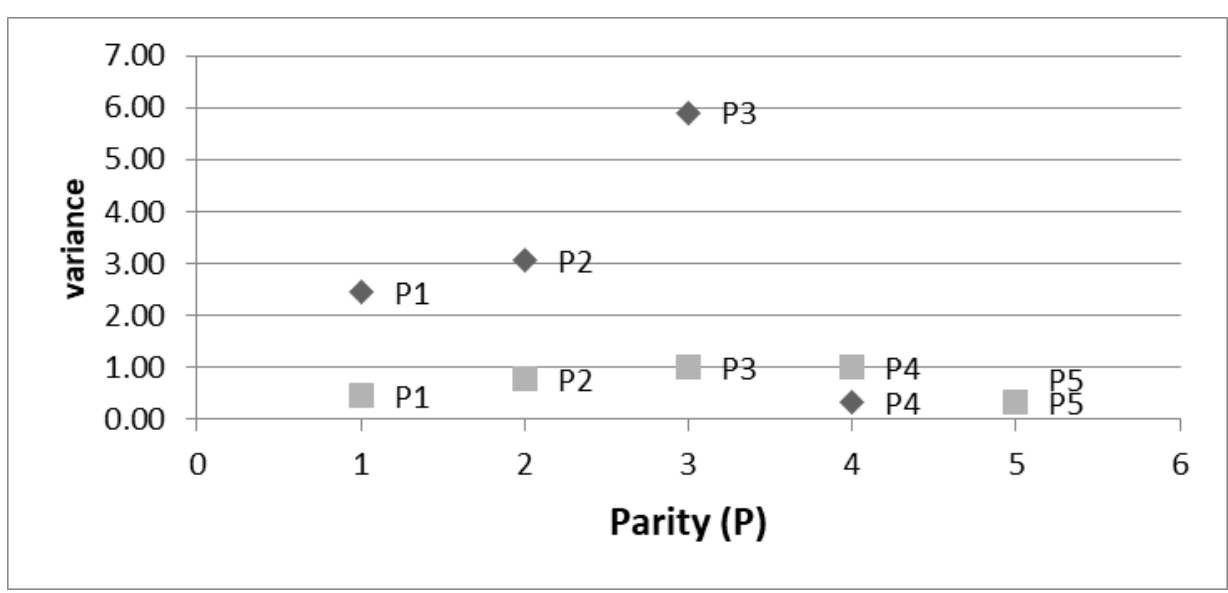

Figure 3: Variance distribution of hip height (trapezoid symbol) and hip-width (rectangular symbol)

Table 2 showed that parity could be predicted from HH and HW even though HW had the correlation value and the coefficient of determination is higher than $\mathrm{HW}, 1.30-2.03 \%$. Based on the coefficient of determination, the effect of $\mathrm{HH}$ on parity is $35 \%$ smaller than the effect of $\mathrm{HW}$ on parity of $36 \%$. Besides that, a variance of $\mathrm{HH}$ greater than HW (Table 1) meant that the size of $\mathrm{HH}$ was more diverse than HW (Figure 3). The conclusion was the size of HW could be used as one of the standard criteria for doe candidates. The excellent HW size for ILEG doe candidates was a minimum of $19.6 \mathrm{~cm}$.

\section{CONCLUSION}

This study concluded that the variance of hip width was smaller (more consistent) than the hip height of Indonesian Local Ettawah Goats. One of the basic selection criteria for Indonesian Local Ettawah doe candidates was hip-width with $19.6 \mathrm{~cm}$ or more.

\section{ACKNOWLEDGMENT}

Thank you to the Government of the Republic of Indonesia through the Ministry of Research, Culture, and Technology and Higher Education for providing research funding so that this preliminary research was being carried out.

\section{REFERENCE}

1. Anggraeni A, Saputra F, Hafid A, Ishak ABL. Jurnal ilmu ternak dan veteriner. 25 (2):4859, (2020).

2. Mudawamah, M., Ciptadi, G., \& Retnaningtyas, irawati D. Animal Production, 23(1), 54-61. (2021) https://doi.org/10.20884/1.jap.2021.23.1.85

3. L Praharani, A Anggraeni and A A R Hapsari. 2019. Heterosis on morphometric traits of crossbreds from Anglo Nubian and Etawah Grade goats. IOP Conf. Series: Earth and Environmental Science 387. Pages 1-4 (2019). doi:10.1088/1755-1315/387/1/012024.

4. Mamy K., M. Syafiee and M. S. R. Rahman. Morphometric characterization of Katjang goat of Malaysia. J. Anim. Sci. 45 (3):17-24, (2016). 
5. Melo D. B. A., I. D. M. Nascimento, D. L. T. A. Santos, D. L. G. Lima, D. F. C. T. Araújo, R. R. S. Rios, A. D. G. Couto \& A. B. Fraga.. 46 (1): 1307-1312, (2018). https://doi.org/10.1080/09712119.2018.1502669

6. Afolayan, R.A., Pitchford, W.S., Deland, M.P.B., and McKiernan. Breed variation and genetic parameters for growth and body development in diverse beef cattle genotype. Animal 1 (1): 13-20, (2007).

7. Hafiz A.W.M., I. Idris, H. yaakub. Pakistan Journal of Biological Sciences 17 (7): $952-$ 955, (2014).

8. Handiwirawan E., R. Noor, C. Sumantri, and S. Subandriyo. Journal of the Indonesian Tropical Animal Agriculture (J. Indonesia Trop.Anim.Agric), vol. 36, no. 1, pp. 1-8 (2011). https://doi.org/10.14710/jitaa.36.1.1-8

9. Rajappa, R., M. R. Nazal, J. W. Stelzer, H. P. Hsu, W. K. Conaway, S. Rokkappanavar, W. Niu, S. Upadhyaya, K. Alpaugh, M. Spector, and S. D. Martin. J. Orthop. Res. 2020 May;38(5):1070-1080, (2019) doi: 10.1002/jor.24546.

10. M.M. Hassan, S.M.N. Mahmud, S.K.M.A. Islam, O.F. Miazi. Univ.J. zool. Rajshahi Univ. 26, 55-57, (2007).

11. D. Duricic, J. Grizelj, T. Dobranic, I. harapin, S. Vince, p. kocila, I. Folnozic, M. Lipar, G.Gragner, and M. Samardzidja. Veterinarski Arhiv. 82, 351-358, (2012).

12. A. Sodiq, S. Adjisoedarmo, and E.S. Tawfik. Proceeding of International research on Food Security, Natural Resource Management and Rural Development. Deutscher TropentagGottingen. 8-10 October: 1-7. (2003).

13. S. Jimmy, M. David, K.R. Donald and M. Dennis. Middle-East Journal of Scientific Research. 5 (2), 98-105. (2010).

14. S. Paul, M. A. M. Y. Khandoker, M. A. Moinuddin and R. C. Paul. J. Bangladesh Agril. Univ. 9 (1), 61-66. (2011)

15. D. Dudhe, S. B. S. Yadav, R. K. Nagda, U. Pannu and G. C. Gahlot. Veterinary World. 8 (15), 1356-1363. (2015).

16. J. Nourinezhad, S. Bamohabat, Y. Mazaheri and K. Kazaeel. Int. J. Morphol. 35 (2), 506514. (2017).

17. G. Erdogan. Reprod Dom Anim 47, 157-163 (2012). 